\author{
An Event Summary
}

\title{
WASHINGTON D.C. AREA 2009-2010 "SNOWMAGEDDON" WINTER SNOWFALLS BURY HISTORICAL RECORDS
}

\author{
Robert J. Leffler \\ National Weather Service, retired 2008 \\ Assistant Maryland State Climatologist 1969-1973 \\ Climate Services Division \\ Silver Spring, MD
}

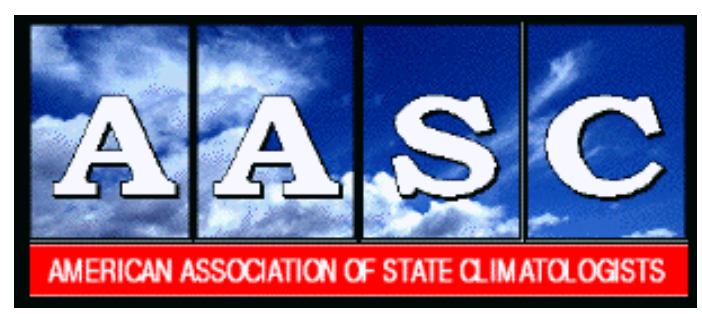

2011

Journal of Service Climatology

Volume 5, Number 3, Pages 1-5

(version 2, edited with corrections)

A Refereed Journal of the American Association of State Climatologists 


\title{
Washington D.C. Area 2009-2010 "Snowmageddon" Winter Snowfalls Bury Historical Records
}

\author{
Robert J. Leffler \\ National Weather Service, retired 2008 \\ Assistant Maryland State Climatologist 1969-1973 \\ Climate Services Division \\ Silver Spring, MD
}

Corresponding Author: Robert J. Leffler, Damascus, MD, USA (postal address withheld by request). Tel. 1-301-253-2747, mdweather@yahoo.com.

\begin{abstract}
The winter of 2009-2010 in the Washington D.C. area will likely be remembered by many area residents as the snowiest in their lifetimes. A rare combination of a weak-to-moderate El Nino (wet) and a very persistent negative North Atlantic Oscillation (NAO) (cold) brought a potent combination of sub-tropical moisture and cold air together over the mid-Atlantic states including the nation's capital, resulting in an unprecedented number of major snowstorms and total snowfall. The extreme winter snowfalls during the most intense periods of the winter earned the winter the nickname "Snowmageddon".

The largest snowfalls occurred to the north of the Capital and west and northwest of Baltimore in north-central Maryland. An analysis of historical snowfall reports for the Washington D.C. metropolitan area suggests Snowmageddon's snowfalls were unprecedented in number and amount since historical reports are available beginning in early colonial times in the early 1600 's.
\end{abstract}

\section{Introduction}

The events of the mid-Atlantic winter of 2009-10 captured the nation's imagination. Several record-breaking storms occurred, first in December 2009 and then again in
February 2010. There were numerous days in February where the Washington D.C. area's snowbound woes were the top story on the national television news networks. Local city and suburban school systems cancelled and/or 
delayed opening classes for up to two weeks while the federal government closed for four full consecutive days (2/8-11/2010, PRESTO 2010) and released early on another (2/5/2011). Some, including President Obama, began referring to the Mid-Atlantic snow onslaught as "Snowmageddon" (Wikipedia, 2010)!

Most only heard the reports from the area's big airports. The three major snowstorms during the winter in the mid-Atlantic region plus numerous other days with measurable snow resulted in all three major local area airports (Baltimore Washington, Washington Dulles, and Washington Reagan National) breaking their alltime seasonal snowfall totals with 77.0, 73.2, and 56.1 inches respectively. The 126 year old Washington D.C. record is the longest of the three (beginning 1886: first at $24^{\text {th }}$ and M Streets until 1941, then at the airport from 1941 to present).

But since no one lives at airports, and conditions there are not always representative of non-airport environments, it is useful to examine what happened elsewhere. Suburban Montgomery County, Maryland, directly adjacent to and north of Washington D.C., with its nearly one million residents, received the most snow so it is examined more closely.

A number of factors combine to produce an average seasonal snowfall in northernmost Montgomery County that is the highest in the immediate surrounding Washington D.C. counties (32 inches), more than double Washington Reagan National Airport's average measurement (15 inches, NCDC 2011). They include a) elevations of up to 900 feet higher than the tidal Potomac (Figure 1), b) location farther away from the moderating temperature influences of the wide tidal portion of the Potomac River, c) a more rural (vs. urban) environment, and, d) a more northern location.

\section{Purpose}

The purpose of this study is to examine and document the magnitude of Snowmageddon's snowfalls in the immediate Washington D.C. metropolitan area and place it in a historical perspective, with emphasis on Montgomery County, MD to the immediate north of the city,

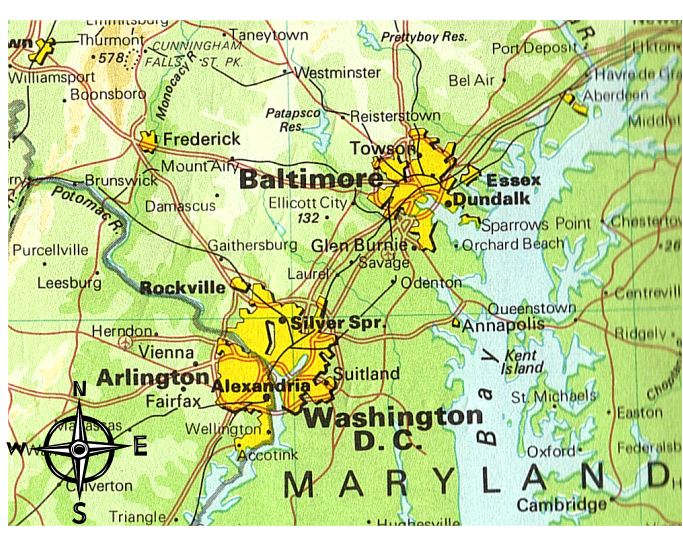

Figure 1: Map of Washington D.C. and Baltimore Areas (scale: one inch $=11$ miles). Urban areas are shown in yellow with elevations colored. The low ridge with elevations of 600 -to-1,000 feet that extends into northern Montgomery County, MD is colored white and includes the town of Damascus and western Baltimore suburbs. Green areas are sea level-to-300 feet elevation. Spot elevations are in meters.

the jurisdiction with some of the greatest snowfall totals in the mid-Atlantic for this event.

\section{Literature Search}

There are snowfall reports from trained National Weather Service observers that come from non-airport locations. Other older snowfall reports from 1604 to 1870 have been summarized in several books by David Ludlum (1966, 1968). This two-volume reference provides the most exhaustive overview of the weather of the early Colonies as documented through newspaper accounts, personal diaries, and contains the earliest documented measurements. Another outstanding resource for northeast snowstorm information is "Northeast Snowstorms (Kocin and Uccellini, 2004). This two-volume reference summarizes big northeastern U.S. snowstorms from the Colonial era (1700's) through 2003.

The snowfall data source for much of the latter reference document is published snowfall measurements collected by the National Weather Service volunteer staffed Cooperative Observer Program (COOP) stations. These measurements are published by the National Climatic Data 
Center. The snowfall data go back to the late 1800's. Recently, an even denser network for various precipitation measurements, including snowfall, was established. It is still expanding and is called the Community Collaborative Rain, Hail, and Snow Network (CoCoRaHS; www.cocorahs.org). Its observations are available via the web and were used in creating Figure 2. This non-government volunteer network's primary purpose is to supplement existing government surface weather observations, with emphasis on snow, hail, and precipitation measurements.

There are issues associated with snowfall measurement that impact our ability to create an accurate historical perspective. The measurement of snow is an inexact science (Doesken and Judson, 1996). Snow settles (compresses), blows around, melts, and accumulates differently depending on its texture (degree of wetness is temperature dependent) and temperature of different surfaces it accumulates on, unlike liquid precipitation. The methodology of measurement (frequency, surface measured on, etc.) also affects the consistency and accurateness of the measurements through time.

Snowfall reports prior to circa 1820 are sketchy, coming from diaries, newspapers, etc. Their nature leaves uncertainty in the completeness, consistency, and accuracy of the early historical record. Nonetheless, these early accounts provide the only source of information we have from snowstorms from those early years.

The size of the largest snowstorm recorded in Montgomery County's history in January 1772 is a good example of how estimated early snowstorm amounts were used. The "Washington and Jefferson Snowstorm" as it is called, is estimated at 36 inches. This amount came from several sources that are complementary, but general. The Maryland Gazette of Annapolis, the nearest newspaper published to present-day Washington D.C. It commented on January 30, 1772 about the great snowstorm "tis supposed the depth where not drifted is upwards of three feet, and it is with utmost difficulty peoples pass for on house to another." Another source was from future President George Washington, then residing at his home in Mount Vernon, Virginia. He entered into his diary "the deepest snow, which I suppose the oldest living ever remembers to have seen in this country." Future President Thomas Jefferson, just back to his home in Charlottesville (Monticello) from his honeymoon entered into his Garden Book "the deepest snow we have ever seen, in Albemarle (VA) it was about 3.f. deep." Another published measurement from Winchester, VA put the amount there at 33 inches. After 1820, information flow and measurements increased, and the sources of snowfall data became more extensive.

With the establishment of a federal weather service in 1871, snowfall measurements became more reliably and consistently measured and

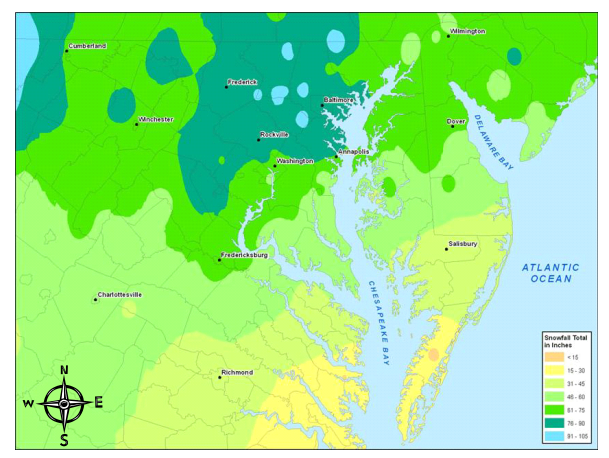

Figure 2: 2009-10 Seasonal Snowfall Total map for the Washington D.C. Area (scale; $1 \mathrm{inch}=32$ miles). Shaded Contours are at a 15-Inch increment. Source: The Washington Post Capital Weather Gang; Map created by Katie Wheatley, 2010. 
documented. However, to this day, there is still some degree of uncertainty regarding reported snowfall amounts due to its previously discussed dynamic nature.

A review of all of the above snowfall sources allows one to create a list of the 15 largest snowstorms in Montgomery County, Maryland's recorded history. The list is presented in Table 1 to the nearest inch so not to suggest undue accuracy. The list should be considered with caution. For example, the propensity of large snowstorms during the $20^{\text {th }}$ century as compared to previous centuries is not necessarily a sign of climate change. It may simply be that more storms were documented in the latter years.

Preliminary unofficial mid-Atlantic wide snowfall amounts for the entire 2009-2010 winter were compiled and published by The Washington Post Capital Weather Gang (Figure 2; The Washington Post 2010). It illustrates the basic pattern and amounts of this incredible winter in the Baltimore-Washington area and especially north-central Maryland.

\section{Results}

A compilation of the snowfall data discussed above yields the following specific snowfall records that appear to easily have been set in Montgomery County, Maryland with Snowmageddon:

a) The 2009-2010 winter total snowfall accumulation of 98.4 inches measured in Damascus is the greatest seasonal amount in the county's history, crushing the previous high of 79 inches in 1995-96 by 19 inches.

b) Three separate storms of 19 inches or more in one winter is unprecedented.

c) The monthly snowfall total of 58.2 inches for February, 2010 is the greatest February monthly snowfall ever and the greatest total for any month. The previous highest monthly total was 40.3 inches in February 2003.

d) The 61.6 inches in only 12 days (Jan. 30 through Feb. 10) in Damascus is the greatest snowfall ever for such a short period of

\begin{tabular}{|c|c|c|c|}
\hline Rank & $\begin{array}{l}\text { Amount } \\
\text { (inches) }\end{array}$ & Date & $\begin{array}{l}\text { Location } \\
\text { in County }\end{array}$ \\
\hline 1. & $36 "(e)$ & Jan. 27-28, 1772 & county-wide \\
\hline 2. & $30 "$ & Jan. 6-8, 1996 & Damascus \\
\hline 3. & 29" & Feb. 5-6, 2010 & Damascus \\
\hline 4. & $28 "(e)$ & Jan. 27-29, 1922 & southernmost \\
\hline 5. & $26 "$ & Feb. 15-17, 2003 & Boyds \\
\hline 6. & $26 "$ & Feb. 11-12, 1983 & Boyds \\
\hline 7. & $24 "(e)$ & Jan. 14-15, 1831 & northernmost \\
\hline 8. & $21^{\prime \prime}$ & Feb. 18-20, 1979 & Brighton Dam \\
\hline 9. & $20 "(e)$ & Feb. 12-14, 1899 & countywide \\
\hline 10. & $20 "$ & Dec. 19, 2009 & Damascus \\
\hline 11. & $19 "$ & Feb. 9-10, 2010 & Damascus \\
\hline 12. & $18^{\prime \prime}$ & Mar. 13, 1993 & Damascus \\
\hline 13. & $17^{\prime \prime}$ & Feb. 23,1987 & Damascus \\
\hline 14. & $17^{\prime \prime}$ & Feb. 15-16, 1958 & Rockville \\
\hline 15. & $17^{\prime \prime}$ & Mar. 29, 1942 & Boyds \\
\hline
\end{tabular}

Table 1: Top 15 Montgomery County, Maryland Snowstorms Ranked by Estimated Amount of Snowfall (to nearest Inch) for the Colonial Period (1600's) to 2011.

Notes: an (e) following the amount in column 2 indicates the snowfall is estimated based on reports and/or surrounding data. Bolded years and amounts highlight storms that occurred during the 2009-2010 winter season. 
time and is greater than 90 percent of all previous seasonal totals. The previous 12 day maximum for published data was 38.6 inches in January 1996.

e) The maximum snow depth of 37 inches on the ground (Feb. 10, 2010) is the greatest depth ever recorded. It resulted from an accumulation of the record 61.6 inches of snow in only 12 days.

f) The December monthly snowfall total of 31.2 inches (Damascus) is the greatest total December monthly snowfall in the county's recorded history. The previous record from published data was 25.3 inches in 1966.

g) The 20-inch snowfall on the December 19, 2010 is the largest single December snowfall ever recorded.

h) The winter included three snowstorms in the top 15 list (ranked by inches of snowfall), third, tenth, and eleventh. No other winter has more than one in the top 15 (Table 1).

The 2009-2010 winter did not contain the largest storm on record ( 36 inches on January 27-28, 1772). Ironically, the extreme winter conditions ended very abruptly in late February and all traces of deep natural snowpack were melted by mid-March.

\section{Conclusions}

Despite issues associated with the accuracy of snowfall measurement and the completeness and consistency of the historical snowfall record, we can still draw some basic conclusions regarding large snowstorms and seasonal totals in the Washington D.C. area and specifically, Montgomery County, Maryland. The most basic observation is that the historical record indicates that many new all-time historical snowfall records were set in this area during the 20092010 winter dating back to the Colonial era (early 1600's).
This winter of 2009-10, billed "Snowmageddon", will indeed be one for conversation for generations in the Washington D.C. area. This analysis suggests it now can also be clearly called "the mother of all winters". It is no doubt the new bench mark for comparison of winter snowfalls totals in this area.

\section{References}

Doesken, Nolan, and A. Judson, 1996. The Snow Booklet; A Guide to the Science, Climatology, and Measurement of Snow in the United States, Colorado State University, Dept. of Atmospheric Science, 86 p.

Kocin, P., and L. Uccellini, 2004: Northeast Snowstorms Vol 1: Overview and Vol.2: The Cases, Boston: American Meteorological Society, $818 \mathrm{p}$.

Ludlum, David, 1966; Early American Winters ; Vol. I: 1604 to 1820, Boston: American Meteorological Society, 217 p.

Ludlam, David, 1968: Early American Winters: Volume II: 1821 to 1870 , Boston: American Meteorological Society, $285 \mathrm{p}$.

National Climatic Data Center (NCDC), 2011. NOAA 1981-2010 Normals, Asheville, NC: National Oceanic and Atmospheric Administration, accessed through: http://ggweather.com/normals/index.htm (web site accessed 9-16-2011)

PRESTO (Precipitation Summary and

Temperature Observations for the Washington, D.C. and Baltimore, MD Areas, Feb. 2010, A. Horvitz, ed., National Oceanic and Atmospheric Administration, National Weather Service, 2 p.

The Washington Post: Capital Weather Gang, 11-3-2010.

http://voices.washingtonpost.com/capitalweather gang/2010/11/dc snow map winter 20092010 html (site accessed 9-17-11)

Wikipedia: (http://en.wikipedia.org/wiki); Obama calls capital's blizzard

"Snowmageddon", Google news. Associated Press (Google), Feb. 6, 2010: (web site accessed 9-15-12)

Photographs taken by the author. 
Some photographs taken by the author.
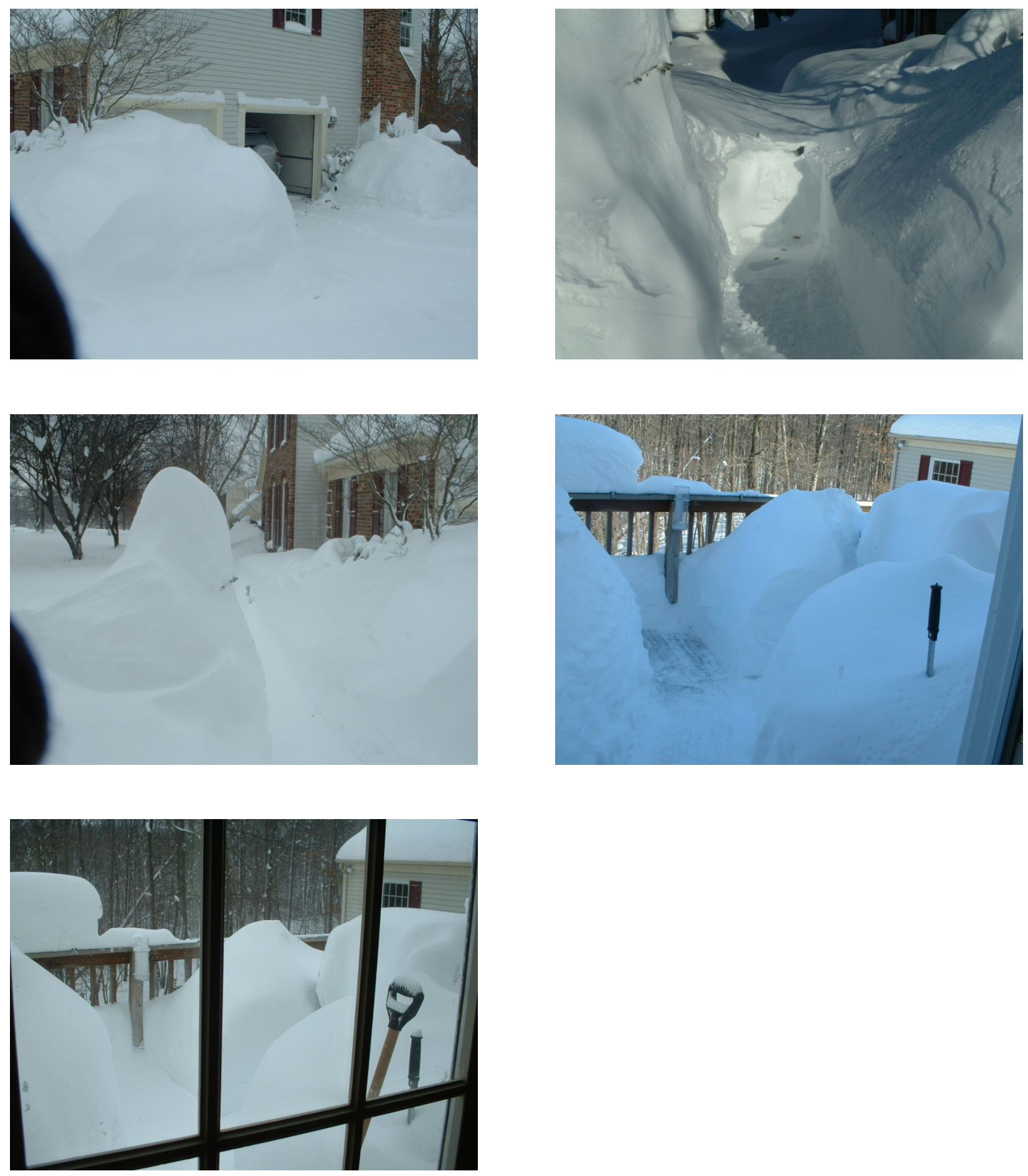